\title{
CrimRxiv
}

\section{Two Sides of a Barricade: (Dis)order and Summit Protest in Europe}

\section{Christian Scholl}

Published on: Jan 01, 2013

DOI: $10.21428 / \mathrm{cb} 6 a b 371.63898020$

License: Creative Commons Attribution 4.0 International License (CC-BY 4.0). 
